\title{
Capital structure and the firm's life stage
}

\author{
A. Frielinghaus, B. Mostert and C. Firer* \\ Graduate School of Business, University of Cape Town, \\ Private Bag, Rondebosch 7701, Republic of South Africa \\ cfirer@gsb.uct.ac.za
}

Received March 2005

\begin{abstract}
In this paper we argue the case for a relationship between capital structure and a firm's life stage. We provide an overview of the two sets of theories and follow this with a proposed linkage between the life stage and capital structure. We use the Adizes life stage model to assess the life stage of the firms in our sample. Our pilot study found a statistically significant relationship between life stage and the capital structure of respondents. The nature of the relationship (more debt in the early and late life stages than in prime) supports the pecking order theory of capital structure and suggests a practical use of the life stage model in helping firms to understand how their financing is likely to change over time.
\end{abstract}

*To whom all correspondence should be addressed.

\section{Introduction}

Much of the ground-breaking work in the field of corporate finance has focused on why firms choose differing proportions of debt and equity to finance their operations. Perhaps the most famous work in this field was the arbitrage argument of Modigliani and Miller (1958) which spawned a flood of research in the area of capital structure. Today there are five major sub-theories within capital structure theory which attempt to explain why capital structure matters and how it contributes to the overall value of the firm. None of the research has proved conclusive, however, and the question is still vigorously debated (Myers, 2001).

One of the five sub-theories proposes that capital structure may be influenced by the organisational life stage of a firm, as financing needs may change with the changing circumstances of the firm (Damodaran, 2001; Bender \& Ward, 1993).

However, capital structure theory and organisational life stage theory are generally approached in isolation. Capital structure research has typically been carried out by researchers with a background in corporate finance or economics, while organisational life stage theory has evolved out of research in the field of strategic management. While the link between capital structure and life stage has been suggested by researchers on the periphery of both fields, it appears never to have been directly tested. The aim of this study, therefore, is to examine the theoretical literature, to synthesise insights from two different academic fields, corporate finance and strategic management, in a way that adds value to both, and finally to undertake a pilot study which investigates the relationship between a firm's life stage and its capital structure.

\section{Literature review}

There has been a great deal of research into both organisational life stage theory and capital structure theory, but relatively little into how the two theories may relate to one another. In order to lay a theoretical framework for our study, we review organisational life stage theory and capital structure theory literature independently. We also explore how and why existing research suggests that there might be a link between the two ideas.

\section{Organisational life stage theory}

The basic premise of organisational life stage theory is that firms - in a similar fashion to living organisms - progress through a set of life stages that starts at birth and ends in death. As a field of study, it first became popular during the 1970s and 1980s (The Economist, 1999).

Black (1998) viewed organisational life stage theory as an extension of product life cycle theory, which evolved from the academic disciplines of marketing and micro-economics ( Rink \& Swan, 1982 ). In this view firms, just like products or services, typically progress through four broad life stages, namely start-up, growth, maturity and decline.

Friesen and Miller (1984) attempted to synthesise much of the research into organisational life stage theory by identifying the stages that are common to most of the literature. They found five common life stages: birth, growth, maturity, revival and decline. They also noted that much of the work in the field is conceptual rather than empirical.

Adizes (1979) found that typical patterns of behaviour emerge at each life stage. He made the key observation that organisational life stages 'are defined by the interrelationship of flexibility and control. They are not 
defined by a company's chronological age, sales or assets, or number of employees' (Adizes, 1996:95).

His model, which we now discuss, incorporates 10 life stages, as opposed to the more common four or five stages.

1. Courtship: This is the life stage during which the business idea is conceived, but the firm has not actually started operating. It therefore has no capital structure. Courtship is an important life stage as it fuels venture creation.

2. Infancy: Should an entrepreneur decide to assume the risk, and commercialise his/her idea, the firm advances to the infancy life stage (Adizes, 2004). Most life stage models start with this stage and refer to it as 'birth' (Friesen \& Miller, 1984). Here the firm's cash flow is negative as it pours cash into its investment schedule. The firm is still small, does not boast extensive reserves and is therefore vulnerable to financial shocks (Marshall \& Heffes, 2004). It thus needs access to external financing. Relationships with early stage investors enable firms at this stage to finance their operations without having to tap into public capital markets (Michelacci \& Suarez, 2004).

3. Go-Go: Once the firm survives the trials and tribulations of infancy it graduates to the go-go life stage. Most literature covering organisational life stages includes this stage as the period during which the firm is converted from start-up to a high-growth enterprise. Marketing assumes a pronounced role during this life stage. In order to satisfy the firm's appetite for growing its sales and its sphere of influence, the firm needs access to even more external capital. Carpenter and Petersen (2002) suggested that a major factor constraining the pace of growth of young firms (infancy) is their limited internal financial resources.

4. Adolescence: Adolescence is very closely aligned with the go-go stage and most life stage models classify these two stages as one - the so-called 'high-growth phase'. Adizes (2004) differentiated between go-go and adolescence by considering the role of the founder and the changing culture of the firm. During this life stage the founder is often supported (sometimes replaced) by professional managers, introduced at the request of outside investors, and management needs to balance the need to grow with the need for profit. Equally important is the financing method through which this growth is pursued and supported. Highgrowth firms often need to advance up the finance chain and introduce private equity investors or rely on an IPO in order to generate funds to sustain growth.

5. Prime: Adizes (2004) described this as the optimal life stage. Here firms operate with maximum efficiency. There is a balance between growth and profits. Company culture is such that employees and stakeholders feel comfortable aligning themselves with the firm. There is a clear focus and the firm pursues its core function with precision. Most importantly, there is a balance between flexibility and control. In most other life stage models this stage may be classified as a transition from growth to maturity.

It has also been argued that at this life stage the risk profile of the firm is lowered, yet the firm still has ample investment opportunities to make it attractive to investors. Goronzy, Andersen and Gray (1974) suggested that firms that have reached an optimal life stage have found a balance between three critical business elements, namely external factors, internal factors and managerial motives.

6. Stable: Firms that enter the stable life stage are finding fewer investment opportunities that promise a return higher than the cost of capital. Most other life stage models refer to this stage as 'maturity'. Analysts regard businesses in this life stage as solid and sound, but don't expect much in terms of growth or future performance. The firm's leadership tends to be satisfied with its size and place in the community.

7. Aristocracy: Adizes (2004) noted that firms entering the Aristocracy stage are operationally successful, financially strong and highly liquid, but there is a marked increase in rigidity. The prevailing sense of organization-wide complacency overpowers the aspirations of any aggressive individuals. People have learned the hazards of proposing risk-taking endeavours. As a result, internal business units make few demands on this cash. Growth comes through acquisition as organic investment opportunities have dried up. Firms in the go-go stage are likely to be pursued. Financiers such as investment bankers and private equity houses play an important role in this life stage.

8. Recrimination: This life stage is dominated by a transformation in firm culture. Instead of promoting innovation, the firm embraces a culture in which no one seeks responsibility and everyone seeks a scapegoat (Adizes, 2004). Once an acquirer, it becomes a take-over target itself. Because financial markets put little to no value on the firm's investment schedule, the firm in recrimination can't turn to public markets to finance its defence and/or rejuvenation. External advisors and so-called 'turnaround artists' play a role in this life stage. Typically capital structure changes, managerial incentives and new business strategies are employed to resuscitate firms in recrimination.

9. Bureaucracy: This life stage often signals the end of the firm, It is largely incapable of generating sufficient resources to sustain itself, and either slips into a full-blown bureaucracy - and is kept alive by artificial interventions rather than market forces - or is consumed by a competitor.

10. Death: At this stage the firm (and its capital structure) cease to exist. Death can also be the result of a merger or acquisition. More often than not it is the strategic option of last resort. Most life stage models cover the last four stages of the Adizes' life stage model in two broad categories namely 'decline' and ‘death'.

The Adizes framework paints a picture of firm development that is consistent with much of the other work that has been done in the field, with the exception that it describes ten life stages, rather than the more usual four or five.

However the notion of organisational life stages is a complex one, and there are questions about how to apply it in practice. Lester, Parnell and Carraher (2003), for example, found that the behaviour patterns attributed to 
different life stages are not necessarily consistent across different studies and that the various life stage models range from as little as three phases to as many as ten. Levie and Hay (1998) claimed that, despite the proliferation of research in the field, researchers have enjoyed no success in proving the existence of a general model of life stages.

Broadly speaking, arguments for the usefulness of organisational life stage theory can be classified in two ways. Some have argued that an understanding of organisational life stages provides management with a compass that can be used to guide the firm's strategic direction, while others have focused on the benefits of organisational life stage theory to understanding how to manage the firm's finances over time.

The objective function of any 'for profit' firm is to maximise the value of the firm. Since value is only created when a firm produces a return on capital that exceeds the cost of that capital (Stewart, 1999), one of management's key objectives is to maximise the life stage during which the firm enjoys superior growth.

Organisational life stage theory offers management some guidelines as to how the characteristics of the firm change over time, and may therefore offer diagnostic tools that indicate how firms can reach and maintain their prime life stage. The better management's understanding of the characteristics of the individual life stages, the higher the probability that management will employ capital in such a way that the firm will continue to outperform its peers (Adizes, 2004).

The ability to understand how to employ and balance tangible and intangible resources as the firm moves from one life stage to the next is critical to the success of the firm (Solomon, Fernald \& Dennis, 2003). Flowing from this, the literature also suggests that there are optimal mixes of the business functions as the firm progress through its life stages (Ellig, 1982; Gomez-Mejia \& Balkin, 1992). One of these functions that changes from one life stage to the next is corporate finance.

Some of the organisational life stage theory research has suggested that changing life stages may require changes in the way the firm is financed. For example Stultz (2000) pointed out that an entrepreneur very often does not have the financial means to convert an idea into a commercial reality. He added that as a firm grows and becomes more established, its shareholding is likely to become more atomistic and it must rely on public markets to finance its existing activities and new investment schedules.

Thus the firm's financing characteristics change from one life stage to the next. In the high-growth phases of infancy, go-go, and adolescence, the firm becomes heavily reliant on external sources of finance as its investment requirements outstrip its accumulated capital and its operating cash flow. But when it reaches prime, the firm has found a balance between growth and profits, and although it still has many good investment opportunities, it can fund these comfortably with internal sources of cash. Should it choose to seek external finance, this is easier for the firm in prime because the risk profile of its cash flows has reduced substantially.

The stable stage sees the firm on the edge of decline. Markets are less receptive to the firm's products, and the firm itself starts to become complacent about its position in the industry. Consequently investment begins to reduce in the stable life stage, and the firm must restructure to regain prime. An aristocratic firm has a strong balance sheet with lots of cash, and tends to grow by acquiring young go-go firms. By the time it reaches the recrimination life stage, the firm is rapidly losing market share and profitability, and financing options like recapitalisations and LBOs start to look attractive. In bureaucracy, the firm has insufficient resources to function and must either be recapitalised or enter death.

For financiers, an understanding of their clients' life stages and growth patterns holds multiple advantages. '... an awareness of the client's specific growth stage and an understanding of where the firm has been and how it got there will help [financiers] better evaluate the firm's financial information, current and future needs, and management capabilities' (Black, 1998:45). Asset managers, too, derive a benefit from understanding organisational life stages as they routinely allocate their funds according to a company's future prospects (Black, 1998).

\section{Capital structure theory}

'One of the most contentious issues in the theory of finance during the past quarter century has been the theory of capital structure' (Bradley, Jarrell \& Kim, 1984:857). Even Stewart Myers, one of the foremost researchers in the field, concluded, as recently as 2001, that 'there is no universal theory of the debt-equity choice, and no reason to expect one' (Myers, 2001: 81).

While there may be a lack of consensus on exactly what drives the capital structure decision, there is no lack of alternative hypotheses. One of these theories, capital structure life stage theory, is conspicuously underdeveloped. Although mentioned in text-books (Damodaran, 2001), mentioned obliquely in some research (for example Morgan \& Abetti, 2004), and even referred to in the development of some of the other major theories (for example Myers, 2001), the idea that the capital structure of a firm may be related to its life stage, appears to have received very little direct theoretical or empirical examination.

We now briefly review the capital structure theories.

1. Static Trade-Off Theory: The debate about how and why firms choose their capital structure began in 1958 (Myers, 2001), when Modigliani and Miller (1958:268) published their famous arbitrage argument showing that 'the market value of any firm is independent of its capital structure'. Based on Modigliani and Miller's valueinvariance theory, we would not expect capital structure to vary from firm to firm, or over the life stages of a single firm. But the theory was developed under a 'deliberately artificial set of conditions' (Barclay, Smith \& Watts, 1995:6) of no information costs, no personal or corporate 
taxes, no contracting or transaction costs, and a fixed investment policy. Unravelling Modigliani and Miller's assumptions introduces us to the other major capital structure theories.

The introduction of taxation effects implies that firms should, theoretically, seek to increase their debt levels as far as possible (Miller, 1988). However other theorists (for example Stiglitz, 1974; 1988) added limitations to the optimal level of firm debt by arguing that bankruptcy costs increase as the firm's level of debt increases, and this places an upper limit on the amount of debt that should be present in a firm's capital structure. This evolved into the static trade-off theory, which proposes that firms attempt to achieve an optimal capital structure that maximises the value of the firm by balancing the tax benefits, with the bankruptcy costs, associated with increasing levels of debt (Myers, 1984).

Some researchers have identified problem areas in the ability of static trade-off theory to explain actual firm behaviour. For example Myers (2001) argued that static trade-off theory implies that highly profitable firms should have high debt ratios in order to shield their large profits from taxation, whereas in reality, highly profitable firms tend to have less debt than less profitable firms. Warner (1977) suggested that bankruptcy costs are much lower than the tax advantages of debt, implying much higher debt levels than predicted by the theory.

There is, however, also some empirical evidence and theoretical support for the idea that firms - at least in part construct their capital structure to take advantage of the interest tax shield (net of the interest tax burden to investors), while ensuring that they avoid incurring excessively high financial distress costs. For example Kayhan and Titman (2004) found that, over the long term, firms do tend to move towards target debt ratios consistent with the theory. Static trade-off theory therefore offers one possible explanation of how firms choose their capital structure. It also provides some important support for capital structure life stage theory.

In his study of bankruptcy costs in the railroad industry between 1933 and 1955, Warner (1977:337) found that the ratio of 'the value of direct bankruptcy costs to the market value of the firm appears to fall as the value of the firm increases, a view that has also found support from Esperenca, Gama and Gulamhussen (2003). We might expect, therefore, to see bankruptcy costs reducing in importance as firms grow and develop, resulting in higher optimal debt ratios and higher levels of debt in larger, more mature firms. Thus, in terms of the Adizes classification of life stages, it would be expected that firms in the life stages from prime to bureaucracy display higher levels of debt.

Opler and Titman's (1994) study of indirect bankruptcy costs among retailers suggested that firms in the infancy, gogo and adolescence life stages should have lower debt levels than firms in later life stages, as their bankruptcy costs are higher.

It has also been argued that 'optimal firm leverage is related inversely to the variability of firm earnings' (Bradley et al.,
1984:876), which suggests that prime and stable firms, with more predictable earnings streams, should have higher debt ratios than younger, less predictable firms.

Graham (2000) found that firms with unique products, low asset collateral or large future growth opportunities - in other words, firms at early stages of development (infancy to adolescence) - tend to have lower levels of debt than firms in the stable or aristocracy life stages.

In summary, static trade-off theory suggests that firms in infancy, go-go and adolescence cannot afford debt as their bankruptcy costs are high, and their earnings are too low to use the tax benefit of increasing interest payments. In the prime and stable stages, the larger, more predictable earnings makes the tax shield advantage of debt more beneficial. Bankruptcy costs are also smaller in the prime and stable life stages. In the stages from aristocracy to death, firms are likely to experience a decrease in earnings (and hence a decrease in the tax shield benefit of debt) and as a result might be inclined to use less debt.

Static trade-off theory thus suggests that the proportion of debt in a firm's capital structure should follow a low-highlow pattern over the firm's life stages.

2. Information Asymmetry Theory: Stephen Ross developed the information asymmetry theory of capital structure by removing another assumption underlying Modigliani and Miller's value invariance theory, namely that 'the market possesses full information about the activities of firms' (Ross, 1977:23). If instead we assume that managers possess information about the firm's future prospects that the market does not have, then managers' choice of a capital structure may signal some of this information to the market (Ross, 1977).

Increasing leverage, he reasoned, would signal to the market that the firm's managers are confident about being able to pay interest in future, and hence are confident about future earnings prospects. Increasing leverage would, therefore, increase the value of the firm by signalling to investors the size and stability of future cash flows (Ross, 1977). Fama and French (1988), on the other hand, countered by pointing to the fact that more profitable firms tend to have lower levels of debt. They argued that increasing debt actually signals poor prospects for future earnings and cash flow as there will be less internal financing available to fund development.

Therefore, while it has been argued that information asymmetries decrease over the lifetime of a firm (Baeyens \& Manigaart, 2003), there is insufficient clarity on exactly how signalling, within the context of information asymmetries, affects capital structure decisions. We cannot, therefore, look directly to information asymmetries, and how they change over time, as an explanation of why capital structure might change over a firm's life stages.

3. Pecking Order Theory: Myers observed how firms actually structure their balance sheets, and found that firms tend to follow a 'pecking order' in financing their projects: 
first they use internal equity, then debt, and only then do they use external equity (Myers, 1984).

In contrast to Ross (1977), who argued that firms use more debt to overcome information asymmetries and signal better prospects, Myers (2001) used information asymmetries to argue that managers are unlikely to issue equity because they fear it will signal that the stock price is overvalued.

In addition to the evidence presented by Myers, several other studies have lent support to pecking order theory. For example Allen (1993), like Fama and French (1988), found that leverage is inversely related to profitability, which supports the pecking order theory view that debt is only issued when there is insufficient retained income to finance investment.

According to the pecking order theory, we might expect firms in infancy, adolescence and go-go, with little retained earnings, to seek the maximum available debt funding before resorting to external equity. Prime and stable firms, in contrast, generate substantial retained earnings and therefore need less debt than they did in their high-growth phase. As they move into the stages of decline, retained earnings will decrease and firms again will increase their debt levels to finance acquisitions of young go-go firms.

Pecking order theory, therefore, also suggests a strong relationship between life stage and capital structure. In contrast to static trade-off theory, however, pecking order theory suggests a high-low-high pattern of debt ratio over time.

4. Agency Cost Theory: There is also another argument for how capital structure may be influenced by asymmetries between managers and investors. Not only do managers have different information about the prospects of the firm than shareholders do, but managers also have interests that diverge from those of shareholders.

Agency costs are a good reason for firms to increase the amount of debt in their capital structure, as debt 'enables managers to bond their promise to pay out future cash flows' (Jensen, 1986:324). According to agency cost theory, firms use more debt in their capital structure when investors seek to pressure management to use funds efficiently.

Fosberg (2004) found that the debt ratio decreases as agency costs decrease because of an increasing proportion of ownership by management, and that those firms with fewer shareholders have more debt than firms with many shareholders. The link between fewer shareholders and more debt suggests that shareholders, who are able to influence capital structure in their favour, do so in a way that increases the level of debt.

Jensen (1986:23) argued that agency costs are especially severe 'when the organisation generates substantial free cash flow', and that the control function of debt is most important in old, declining organisations that actually need to shrink. In the context of the Adizes life stage model this suggests that firms in the prime, stable, aristocracy, recrimination and bureaucracy life stages should take on more debt to control agency costs.

Jensen also argued that debt is less effective in reducing agency costs in rapidly growing organisations with 'large and highly profitable investment projects but no free cash flow' (Jensen, 1986:324). The firm with the lowest agency costs is, by definition, the one that is run by its owner (Ang, Cole \& Lin, 2000) and therefore one would expect start-up firms (the infancy, go-go and adolescence life stages) that are run by the entrepreneur to have the least debt.

The agency cost argument therefore also offers support for capital structure life stage theory. This time, however, the pattern of the relationship pattern is low-high-high. In terms of agency cost theory, we would expect young ownermanaged firms to have the least debt, and that debt levels will gradually increase as the firm develops and acquires a greater number of shareholders and more professional managers.

5. Capital Structure Life Stage Theory: Some theorists have approached the problem of how organisational life stage relates to capital structure. Bender and Ward (1993) focused on the trade-off between business risk and financial risk, positing that business risk reduces over the life stages of a firm, allowing financial risk to increase.

Hovakimian, Opler and Titman (2001:2) offered a similar view, stating that 'firms should use relatively more debt to finance assets in place and relatively more equity to finance growth opportunities', and should, therefore, use progressively more debt in their financing mix as they mature. This is supported by Damodaran (2001) who proposed that expanding and high-growth firms would finance themselves primarily with equity, while mature firms would replace equity with debt.

Capital structure life stage theory would seem to suggest, therefore, that debt ratios should increase as the firm progress through the early life stages. From an empirical point of view, however, little work has been done to support or refute this idea. Most of the evidence for and against appears in the context of other arguments. In their analysis of the venture-capital financing of biotech ventures, for example, Morgan and Abetti (2004:13) argued that high technology ventures are so risky that they can only be financed by 'venture capital and private equity sources', a view that supports the theory that riskier firms in the infancy, adolescence and go-go life stages should use more equity.

There has been little research focusing directly on capital structure life stage theory, but the little there is suggests, in line with static trade-off theory, that debt ratios should follow a low-high-low pattern over the firm's life. Firms in infancy, go-go and adolescence have a high business risk and cannot afford financial risk, while firms in prime and stable can afford the extra risk that accompanies debt financing. Firms in the declining life stages would again experience a growth in business risk and would need to decrease their exposure to debt. 
In Table 1 we summarise, in a simplified format (grouping the first eight Adizes life stages - excluding courtship and death, in which there is no capital structure - into three organisational life stages) what each of four capital structure theories implies about the amount of debt in a firm's capital structure over different life stages. Information asymmetry theory is excluded as it does not offer a clear guide to the capital structure decision.

Table 1: The expected level of debt usage in three life stages as predicted by capital structure theories

\begin{tabular}{l|l|l|l}
\hline \multicolumn{1}{c|}{ Theory } & \multicolumn{1}{c|}{ Early: } & Prime: & \multicolumn{1}{c}{ Late: } \\
\hline & $\begin{array}{l}\text { Infancy } \\
\text { Go-Go } \\
\text { Adolescence }\end{array}$ & $\begin{array}{l}\text { Prime } \\
\text { Stable }\end{array}$ & $\begin{array}{l}\text { Aristocracy } \\
\text { Recrimination } \\
\text { Bureaucracy }\end{array}$ \\
\hline Static Trade-Off & Low & High & Low \\
\hline $\begin{array}{l}\text { Capital Structure Life } \\
\text { Stage }\end{array}$ & Low & High & Low \\
\hline Agency Cost & Low & High & High \\
\hline Pecking Order & High & Low & High \\
\hline
\end{tabular}

On the basis of our review, there is a persuasive argument in favour of a low-high-low pattern. We therefore set out to establish whether there is in fact a relationship between capital structure and life stage, and what the nature of the relationship might be.

\section{Research hypothesis}

With this objective in mind, the following research hypothesis was formulated.

\section{There is a relationship between a firm's capital structure} and its life stage.

\section{Methodology}

Most of the life stage models developed by academic researchers over the last three decades rely on a questionnaire-based life stage assessment methodology (for example Lester et al., 2003). However, of the assessment tools reviewed, only the Adizes LifeCycle Assessment Tool тM has seen extensive use in a practical setting. Since its development was started in the early seventies by Dr Ichak Adizes, it has been updated and modified, through the Adizes consulting practice, to measure firm life stages with increasing accuracy. We felt that the extensive use of the Adizes LifeCycle Assessment Tool TM in commercial settings implied a level of reliability higher than that of the more academic models. We contacted the Adizes Institute and permission was granted to use the Adizes LifeCycle Assessment Tool $\mathrm{TM}$ as the diagnostic instrument for assessing organisational life stage.

While Levie and Hay (1998) found that no general theory on life stage assessment existed, a common denominator seemed to be that life stage is determined via the personal interpretation by executives of company culture, data, prospects, history and strategy. In some instances only one manager is interviewed (Lester et al., 2003) and in others multiple managers are interviewed (Adizes, 2004). No empirical evidence exists to validate the optimal number of respondents needed per company to determine organisational life stage.

The questionnaire was designed to be self-administered. The ideal approach to measuring capital structure would have been to gain access to firms' balance sheets, so that we could control the definition and measurement of the term consistently across different firms. Since we did not have access to balance sheets, we asked respondents for the necessary balance sheet information. The ratio of total interest-bearing debt / capital was used as the measure of capital structure.

The identified population was domestic and multi-national firms with ongoing operations in South Africa. In order to draw a representative sample it was hoped to obtain the cooperation of one of South Africa's four major banking groups, since all firms, regardless of their capital structure or life stage, need a bank account and therefore a sample drawn from the client-base of a bank would have offered minimal selection bias.

Although one group was very interested and requested a formal proposal, at the eleventh hour they perceived that there was a business risk in inconveniencing clients by requesting them to partake in this study so soon after the then deadline for compliance with the requirements of the Financial Information Centre Act (FICA) of 2002 of October 2004, and they withdrew from the study.

Consequently it was decided that, given the time limitations on the study and the probability that similar responses would be forthcoming from the other large banking groups, a convenience sample would be used.

A list containing 4400 private and public firms in South Africa with published email addresses was drawn from the McGregor BFA database and the questionnaire emailed to them. The questionnaire was also distributed to 220 South African companies with whom telephonic contact had been made. Unfortunately only 81 usable responses were received, sufficient only for a pilot study. Hopefully in the future a major bank will provide the necessary access and encouragement to allow for an extended and detailed study.

\section{Data analysis}

\section{Overview of the sample}

The respondents were evenly distributed across seven industry sectors: consumer goods, financial services, manufacturing, resources, services, technology and media and 'other'. We show the distribution of the number of shareholders in the firms making up the sample in Table 2.

The majority of our responses came from public (41,5 percent) and private ( 48,8 percent) companies. We received no responses from partnerships or sole proprietorships, and only five from closed corporations. Many of the small firms we spoke to felt that the questions were not relevant to them. 
Table 2: Shareholder distribution of respondents

\begin{tabular}{l|c}
\hline \multicolumn{1}{c|}{ Number of shareholders } & Proportion of sample \\
\hline Less than 5 & $37,8 \%$ \\
\hline 5 to 20 & $10,0 \%$ \\
\hline $20-100$ & $3,7 \%$ \\
\hline More than 100 & $47,6 \%$ \\
\hline
\end{tabular}

Given the concentration of private and public companies, relative to SMEs and single proprietorships, in our sample, it is not surprising that we also find a high concentration of firms in the prime and stable life stages. Responses from more small firms might have increased the proportion of firms in the infancy, go-go and adolescence life stages.

There is also a chance that our research has undercounted firms in the aristocracy, recrimination and bureaucracy life stages. We asked senior managers to answer the questionnaire, and since we expect senior managers to be biased towards seeing their company in a more favourable light, we may have some response bias in the life stage ratings.

Since courtship and death are beyond the active life stages of the firm, we did not expect to diagnose any firms in these categories.

\section{Hypothesis test}

The purpose of the study was to establish if there is a relationship between a firm's capital structure and its life stage. To test this hypothesis we needed to test for a relationship between a categorical variable (life stage) and a numeric value (capital structure, represented here by the debt / capital ratio).

The analysis of the sample, using a box-and-whisker plot (Figure 1) suggests that firms in infancy use relatively little debt. They increase their debt ratio as they move through the high-growth life stages of go-go and adolescence. When they reach their most productive life stages, prime and stable, they seem to need the least debt. And in the latter life stages through aristocracy and recrimination, firms once again increase their debt levels.

Since the data was not normally distributed, the nonparametric Kruskal-Wallis test was employed to test the hypothesis as follows:

$\mathrm{H}_{0}$ : The median debt ratios of all 10 life stage populations are the same

$\mathrm{H}_{1}$ : At least two population debt ratio medians differ

Insufficient evidence was found to reject the null hypothesis and we conclude that there is not a statistically significant relationship between life stage and capital structure.
However, the box-and-whisker plot also suggests there may be merit in grouping different life stages together. For example, the go-go and adolescence life stages are remarkably similar in terms of their debt ratio.

From a theoretical point of view, there also appears to be merit in grouping some of the life stages for the purposes of this study. For example, in the literature review, we noted that Adizes describes both go-go and adolescence as life stages in which investment exceeds income and external funding is needed. From a financing perspective, there are strong similarities between pairs of life stages: while go-go and adolescent firms consume outside capital, prime and stable firms generate cash exceeding their investment needs, and firms in aristocracy and recrimination are fast running out of income while they try to invest in younger go-go firms.

We therefore grouped the life stages as follows: go-go with adolescence; prime with stable; and aristocracy with recrimination. Since the samples for the infancy and bureaucracy life stages were very small, we excluded them from our newly grouped sample. The new groupings are shown in Table 3.

Table 3: Reclassification of the Adizes life stages into three broad stages

\begin{tabular}{l|l}
\multicolumn{1}{c|}{ Adizes Life Stage } & \multicolumn{1}{c}{ New Life Stage } \\
\hline Infancy & [Excluded] \\
\hline Go-Go & Early \\
\hline Adolescence & Early \\
\hline Prime & Prime \\
\hline Stable & Prime \\
\hline Aristocracy & Late \\
\hline Recrimination & Late \\
\hline Bureaucracy & {$[$ Excluded] } \\
\hline
\end{tabular}

This reorganisation of the data resulted in a much clearer pattern of capital structures, as shown in Figure 2.

Testing the relationship between this simplified life stage model and capital structure revealed a statistically significant relationship between life stage and capital structure. Furthermore, inspection of the box-and-whisker plot indicated that the relationship between the two variables is of a high-low-high pattern.

Although life stages were grouped to achieve this result, the groupings are supported by the underlying theory. With a larger sample, however, it may be possible to discern a significant relationship between life stage and capital structure without having to group life stages together. 


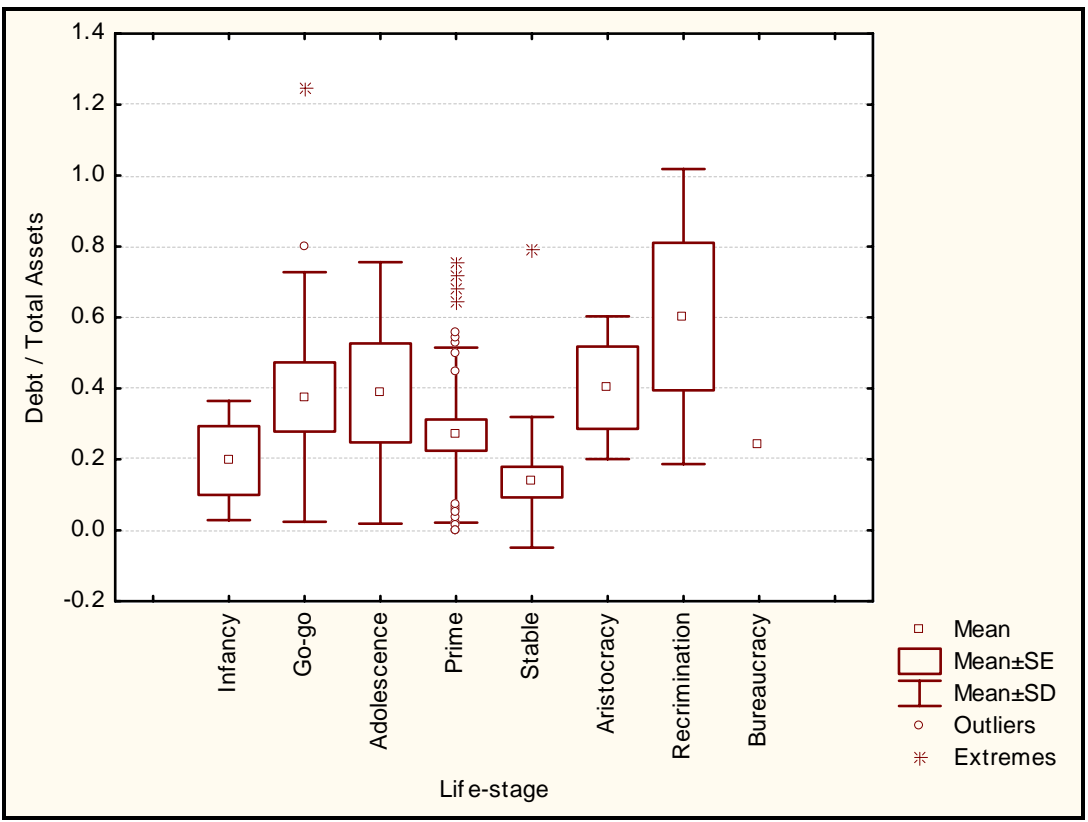

Figure 1: Box and whisker plot of respondents classified per life stage to debt/total assets

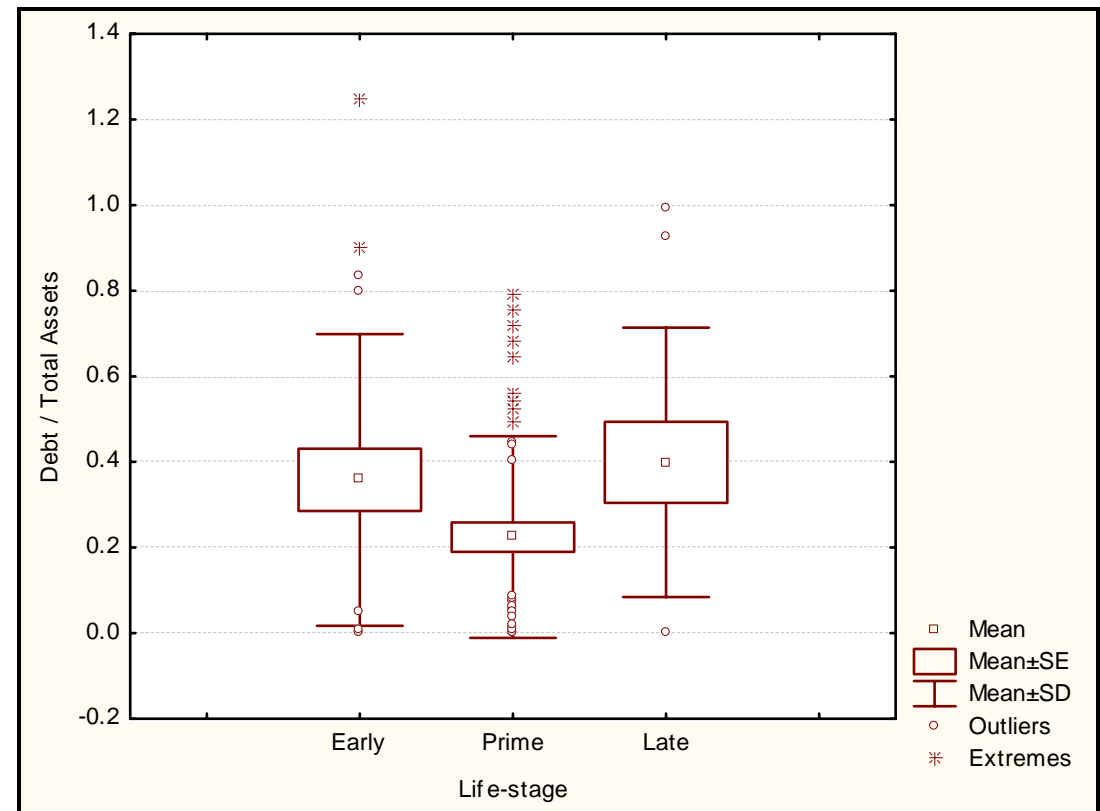

Figure 2: Box and whisker plot of three stage life stage classification to debt/total assets

\section{Interpretation of results}

This study provides some empirical support for the idea that life stage and capital structure are related. Thus life stage analysis can be viewed as a means for gaining insight into what a firm's capital structure is likely to be at any given time. Finance directors can use the tool to evaluate their financing policy, and analysts and investors can use the tool (assuming they can assess the firm's life stage) to understand a firm's capital structure in the context of its life stage development. The existence of the link between capital structure and life stage, and more importantly the nature of that link, also provides some insights into the body of established capital structure literature used to develop the research hypothesis.
We find no support for the static trade-off theory of capital structure. We argued that static trade-off theory predicts that firms should have less debt in the early and late life stages, and the most debt in the prime stage, when bankruptcy costs are lowest and the tax shield benefits highest. We find the opposite.

It may be that our inferences were wrong about how static trade-off theory would predict capital structure changes over the firm's life stages. It is possible, for example, that firms in the highly profitable prime stage don't feel the need to gain any additional advantage through financing as they are already on top of their industries. This possibility could be tested by future research. On the whole, however, the static trade-off theory does not appear to be supported by these findings. 
Pecking order theory argues that firms have a hierarchy of preferred financing: first internal equity, then debt if retained earnings are insufficient to finance investment, then external equity in a worst case scenario. Pecking-order theory suggests the results we find, namely that firms in the early and late life stages (which typically have less internal funding than they require) use more debt than cash-rich firms in prime. Our study therefore provides support for Myers' pecking order theory, and extends it by showing how the pecking order is affected by the different life stages through which firms progress.

We also find support for related work by Fama and French (1988), Allen (1993) and Myers (2001) that showed leverage and profitability to be inversely related, and for Sexton, Pricer and Nenide (2000), who argued that firms are more profitable if they grow without external funding. Because of this, we also find that capital structure decisions may in fact overcome information asymmetries by signalling information to the market. But because more debt is associated with lower profitability and unattractive life stages, we find favour with Fama and French's (1988) argument that increasing debt signals negative future prospects, rather than with Ross' (1977) argument that more debt signals positive news about the future.

Our findings do not provide much support for agency cost theory, which suggests firms should take on progressively more debt as they develop. Agency cost theory claims that firms with substantial free cash flow (stable), and firms in the decline stages, have higher agency costs and therefore should have higher debt levels. While we find that firms in latter stages do, in fact, have more debt than firms in prime, agency theory cannot explain why firms in the early stages of development, with managers owning more of the firm, have more debt than firms in prime. It is possible that firms in the early life stages have very strong external shareholders, in the form of venture capitalists, who enforce high debt levels which the more dispersed shareholders of prime firms cannot do. This is another avenue for further research.

Ironically, our findings do not support the bulk of the existing theory that concerns itself directly with the relationship between capital structure and organisational life stage. Most arguments in this area focus on the trade-off between financial risk and business risk, and suggest that firms in the early life stages should have less debt to compensate for higher business risk, while firms in the prime stages should have as much debt as possible. Our findings contradict this view and suggest that business risk is not a major consideration in the capital structure decision.

Finally, the fact that we find a link between capital structure and the life stage suggests that life stage analysis has a practical use in corporate finance that has not been fully explored, and that corporate finance practitioners seeking to understand the life stage of a firm, with a view to understanding its capital structure needs, should consider the using Adizes LifeCycle Assessment Tool TM.

\section{Conclusion}

In conclusion, this paper has argued the case for a relationship between capital structure and a firm's life stage. We provide an overview of the two sets of theories and follow this with a proposed linkage between the life stage and capital structure. The empirical study produced some interesting results with consequences for organisational life stage theory and capital structure theory, and for practical applications in the corporate finance field.

But it is very much a pilot study. It would need the cooperation of a major bank to reach a broad and deep sample. This would allow access to firm balance sheets, which would provide for more accurate assessment of capital structure. The larger sample would allow for more precise conclusions to be drawn about the significance of individual Adizes life stages, and perhaps remove the need to group them.

\section{References}

Adizes, I. 1979. 'Organizational passages - Diagnosing and treating lifecycle problems of organisations', Organizational Dynamics, 8 (1):3-25.

Adizes, I. 1996 . 'The 10 stages of corporate life cycles', Inc., 18 (14):95-97.

Adizes, I. 2004. 'Adizes - Resources for sustainable exceptional performance'. [online] URL: www.adizes.com. Accessed 16 November 2004.

Allen, D. E. 1993. 'The pecking-order hypothesis: Australian evidence', Applied Financial Economics, 25(1):101-112.

Ang, J. S., Cole, R. A. \& Lin, J. W. 2000. 'Agency costs and ownership structure', The Journal of Finance, 55 (1):81-106.

Baeyens, K. \& Manigaart, S. 2003. 'Dynamic financing strategies: The role of venture capital', Journal of Private Equity, 7(1):50-58.

Barclay, M. J., Smith, C.W. \& Watts, R. L. 1995. 'The determinants of corporate leverage and dividend policies', Journal of Applied Corporate Finance, 7(4):4-19.

Bender, R. \& Ward, K. 1993. Corporate financial strategy. Oxford: Butterworth-Heinemann.

Black, E.L. 1998. 'Life-cycle impacts on the incremental value relevance of earnings and cash flow measures', Journal of Financial Statement Analysis, 4(1):40-56.

Bradley, M., Jarrell, G. A. \& Kim, E. H. 1984. 'On the existence of an optimal capital structure: Theory and evidence', The Journal of Finance, 39(3):857-880. 
Carpenter, R.E. \& Petersen, B.C. 2002. 'Is the growth of small firms constrained by internal finance?', Review of Economics and Statistics, 84(2):298-310.

Damodaran, A. 2001. Corporate finance: Theory and practice. New York: John Wiley and Sons.

Ellig, B.R. 1982. 'Compensation elements: Market phase determines the mix’, Compensation Review, 13(3) : 30-38.

Esperenca, J. P., Gama, A. P. M. \& Gulamhussen, M. A. 2003. 'Corporate debt policy of small firms: An empirical (re)examination', Journal of Small Business and Enterprise Development, 10(1):61-80.

Fama, E. F. \& French, K. R. 1988. 'Taxes, financing decisions and firm value', The Journal of Finance, 53(2):819-844.

Fosberg, R. H. 2004. 'Agency problems and debt financing: leadership structure effects', Corporate Governance, 4(1):31-38.

Friesen, P.H. \& Miller, D. 1984. 'A longitudinal study of the corporate life cycle’, Management Science, 30(10):11611183.

Gomez-Mejia, L.R. \& Balkin, D.B. 1992. Compensation, organizational strategy and firm performance. Cincinnati, Ohio: Southernwestern.

Goronzy, F., Andersen, A. \& Gray, E. 1974. 'Factors in corporate growth', Management International Review, 14(4/5):75-90.

Graham, J. R. 2000, 'How big are the tax benefits of debt?', The Journal of Finance, 55(5): 1901-1942.

Hovakimian, A., Opler, T. \& Titman, S. 2001. 'The debtequity choice', Journal of Financial and Quantitative Analysis, 36(1):1-24.

Jensen, M. C. 1986. 'Agency costs of free cash flow, corporate finance and takeovers', American Economic Review, 76(2):323-330.

Kayhan, A. \& Titman, S. 2004. 'Firms' histories and their capital structures’. NBER Working Paper, May.

Lester, D.L., Parnell, J.A. \& Carraher, S. 2003. 'Organizational life cycle: A five-stage empirical scale', International Journal of Organizational Analysis, 11(4):339-355.

Levie, M. \& Hay, P. 1998. 'Progress or just proliferation? A historical review of stages of models of early corporate growth’. Working Paper, London Business School.

Marshall, J. \& Heffes, E.M. 2004. 'Smaller firms most vulnerable to problems’, Financial Executive, 20(7): 11.

Michelacci, C. \& Suarez, J. 2004. 'Business creation and the stock market', Review of Economic Studies, 71(2):459-482.
Modigliani, F. \& Miller, M. 1958. 'The cost of capital, corporation finance and the theory of investment', The American Economic Review, 48(3): 261-281.

Miller, M. 1988, 'The Modigliani-Miller Propositions after Thirty Years', Journal of Economic Perspectives, 2(4) : 99121.

Morgan, Jr, I. W. \& Abetti, P. A. 2004. 'Private and public 'cradle to maturity' financing patterns of U.S. biotech ventures', The Journal of Private Equity, 7(2):9-26.

Myers, S. C. 1984. 'The capital structure puzzle', The Journal of Finance, 39(3):575-583.

Myers, S. C. 2001. 'Capital structure', Journal of Economic Perspectives, 15(2):81-102.

Opler, T. C. \& Titman, S. 1994. 'Financial distress and corporate performance', The Journal of Finance, 49(3): 1015-1040.

Rink, D.R. \& Swan, J.E. 1982. 'Fitting market strategy to varying product life cycles’, Business Horizons, 25(1):7277.

Ross, S.A. 1977. 'The determination of financial structure: The incentive-signalling approach', The Bell Journal of Economics, 8(1):23-41.

Sexton, D.L, Pricer, R.W. \& Nenide, B. 2000. 'Measuring performance in high growth firms'. Babson Entrepreneurship Research Conference, Wellesley, Mass, June.

Solomon, G., Fernald, L.W. \& Dennis, W. 2003. 'Selfidentified management deficiencies of entrepreneurs', Journal of Private Equity, 7(1):26-35.

Stewart, G.B. 1999. The quest for value - A guide for senior managers. New York:Harper Business.

Stiglitz, J.E. 1974. 'On the irrelevance of corporate financial policy', The American Economic Review, 64(6):851-867.

Stiglitz, J.E. 1988. 'Why financial structure matters', Journal of Economic Perspectives, 2(4):121-127.

Stultz, R.M. 2000. 'Financial structure, corporate finance and economic growth', International Review of Finance, 1:11-40.

The Economist, 352(8128)1999:70 'The corporate growth puzzle'.

Warner, J. B. 1977. 'Bankruptcy costs: Some evidence' The Journal of Finance, 32(2): 337-348. 